\section{Adverse reactions to cosmetic products and the Notification System in Health Surveillance: a survey}

\section{Reações adversas aos produtos cosméticos e o Sistema de Notificação em Vigilância Sanitária: um inquérito}

\section{Gisele Huf'}

Priscila da Nobrega Rito"

\section{Rosaura de Farias Presgrave'}

\section{Maria Helena Simões Villas Bôas'}

'National Institute of Quality Contrl in Health of Fundação Oswaldo Cruz - Rio de Janeiro (RJ), Brazil.

"Postgraduate Program in Health Surveillance of the National Institute of Quality Control in Health of Fundação Oswaldo Cruz - Rio de Janeiro (RJ), Brazil.

Corresponding author: Priscila da Nobrega Rito. Instituto Nacional de Controle de Qualidade em Saúde da Fundação Oswaldo Cruz. Avenida Brasil, 4365, CEP: 21040-900, Rio de Janeiro, RJ, Brazil. E-mail: prifarm@uol.com.br

Conflict of interests: nothing to declare.

\section{Abstract}

Introduction: This paper is part of a study that investigates the quality of cosmetic products and evaluates the cosmetic surveillance system. Objective: This study presents the results of a research that aimed to describe the point of view of the population in terms of the prevalence of Adverse Reactions (AR) and information about the surveillance system. Methods: A structured questionnaire was applied to a random sample of 200 people from the administrative staff of the Municipal Guard of Rio de Janeiro. Results: $38 \%$ of the participants declared AR to some cosmetic product used in the past two years. Conclusion: To our knowledge, this is an unpublished study in Brazil, which presents results regarding the estimated prevalence of AR similarly to international studies.

Keywords: Data collection. Cosmetics. Notice. National health surveillance agency. Health surveillance. Quality control. 


\section{Resumo}

Introdução: Este trabalho integra um estudo que investiga a qualidade dos produtos cosméticos e avalia o sistema de cosmetovigilância. Objetivo: Ele apresenta os resultados de um inquérito cujo objetivo foi descrever o ponto de vista populacional em termos da prevalência de Reações Adversas (RA) e informações sobre o sistema de vigilância. Métodos: Um questionário estruturado foi aplicado a uma amostra aleatória de 200 funcionários administrativos da Guarda Municipal do Rio de Janeiro. Resultados: $38 \%$ dos participantes declararam RA a algum produto cosmético utilizado nos últimos dois anos. Conclusão: Pelo nosso conhecimento, este é um estudo inédito no Brasil que apresenta resultados em relação à prevalência de RA estimados de forma semelhante aos das pesquisas internacionais.

Palavras-chave: Coleta de dados. Cosméticos. Notificação. Agência nacional de vigilância sanitária. Vigilância sanitária. Controle de qualidade.

\section{Introduction}

The term "cosmetics and hygiene products" refers to products destined to protection and beauty, which consists of four categories: hygiene products, cosmetics per se, perfumes and child use products ${ }^{1}$. It is possible to say that its use is universal, and it is believed that such products have a reasonable degree of safety and tolerability. Even though most adverse reactions (AR) to cosmetics is not severe and is usually related to the skin, there are some severe cases reported in literature related to perfumes, fragrances, and hair dye. Several compounds have been pointed out as being the most common causes of allergic reactions to cosmetics, such as the para-aminobenzoic acid, cinnamate, essential oils, p-phenylenediamine and preservatives ${ }^{2}$.

In most European countries there is not a formal cosmetic surveillance system and, according to some authors, this is the main factor for the absence of notifications of AR to cosmetics ${ }^{2}$. In 2005, the Brazilian Health Surveillance Agency (Anvisa) began to invest in the strengthening of the post-use surveillance/ commercialization of products under health surveillance, including cosmetic surveillance ${ }^{3}$. Then, the Notification System in Health Surveillance (NOTIVISA) was created to notify adverse events (AE), technical complaints and intoxications related to these products ${ }^{3}$. This paper describes the point of view of the user: prevalence of informed AR and information about the NOTIVISA system, which is part of a broader study that investigates the quality of cosmetic products and assesses the Cosmetic Surveillance System.

\section{Methods}

\section{Study design and location}

This is a cross-sectional study conducted with a random sample of 200 administrative employees of the Municipal Guard of Rio de Janeiro. At the time of the study, from November 2011 to December 2012, the Municipal Guard had 578 administrative employees. 


\section{Eligibility criteria}

Participants were selected through the assortment of a list provided by the board of Human Resources. Inclusion criteria were: being older than 18 years old and agreeing to participate by signing the informed consent form. Those with hearing and visual impairment were excluded. In case of refusal, the next name in the list was selected.

\section{Instrument}

A structured questionnaire previously validated with the employees of National Institute of Quality Control in Health, who were sorted from a list provided by the Human Resources coordination of this institution, was applied by a trained professional. The questionnaire had ten closed questions, approaching the following fields: name, gender, age, schooling, evidence of any AR in the past two years, classification of the severity of the reaction, type of reaction, if this reaction was informed to any instance, if the product had been used according to the manufacturer's instructions and if the interviewee knew about NOTIVISA.

\section{Sample size calculation}

In order to calculate the sample size, prevalence estimates of AR of $25 \%$ were used, with $95 \%$ confidence level and margin of error of the sample of $5 \%$; then, the questionnaire was applied to 195 individuals.

\section{Data analysis}

For categorical variables, the proportions and $95 \%$ confidence intervals were calculated. For continuous variables, mean and standarddeviation were used. A bivariate analysis tried to identify possible factors associated with the occurrence of AR to cosmetics. The data base created to manage the information was built with the software Epi Infov.3.3.2 and for data analysis the used software was SPSS 20.0. This study was approved by the Research Ethics Committee of Fundação Oswaldo Cruz (FIOCRUZ), protocol n. 583/11.

\section{Results and Discussion}

Seven individuals refused to participate, being properly replaced by the names that followed theirs in the list. At total, 200 individuals participated in the study. The sample was comprised of individuals aged at least 18 years old, however, the sample varied with participants aged from 12 to 60 years old, mean of 37.8 years old (SD = 8.2). Only $1.5 \%$ of theinterviewees claimed to know the NOTIVISA system. Seventy-six individuals, corresponding to $38 \%$ of the sample (95\%CI35.6-44.9), declared AR to some cosmetic product used in the past two years. The percentage distribution of individuals according to AR occurrence and sociodemographic variables is presented in Table 1. The observed differences

Table 1 - Percentage of individuals who presented adverse reactions to cosmetics over the past two years according to sociodemographic variables.

Tabela 1 - Percentual de indivíduos que apresentaram eventos adversos a cosméticos nos últimos dois anos de acordo com variáveis sociodemográficas.

\begin{tabular}{|c|c|c|c|c|}
\hline $\begin{array}{l}\text { Items of the } \\
\text { questionnaire }\end{array}$ & $\begin{array}{c}\text { Adverse Reaction } \\
(\mathrm{n}=76) \\
\%(95 \% \mathrm{Cl})\end{array}$ & $\begin{array}{c}\text { No Adverse Reaction } \\
(\mathrm{n}=124) \\
\%(95 \% \mathrm{Cl})\end{array}$ & $\begin{array}{c}\text { Total } \\
(\mathrm{n}=200) \\
\%(95 \% \mathrm{Cl})\end{array}$ & $p$-value \\
\hline Male gender & $42.1(31.6-53.3)$ & $48.4(39.8-57.1)$ & $46.0(39.2-52.9)$ & 0.465 \\
\hline $\operatorname{Age}^{*}$ & $37.9(9.1)$ & $37.7(7.8)$ & $37.8(8.2)$ & \\
\hline Complete high school & $51.3(40.3-62.2)$ & $41.9(33.6-50.7)$ & $45.5(38.7-52.4)$ & 0.242 \\
\hline $\begin{array}{l}\text { Knows the NOTIVISA } \\
\text { system }\end{array}$ & $3.9(1.3-11.0)$ & $0(0-0.03)$ & $1.5(0.5-4.3)$ & 0.054 \\
\hline
\end{tabular}

* Mean (Standard deviation).

*Média (desvio padrão). 
were not statistically significant. The main categories of products that caused AR pointed out in this study are soap, shampoo and deodorants: the soap presented 19 mild and 3 moderate reactions; the shampoo, 11 mild, 6 moderate and 1 severe reaction; and the deodorant, 3 mild, 10 moderate and 2 severe reactions. Only three individuals claimed to not have used the product according to the recommendations of the manufacturer in the label, and no product was indicated by professionals. The expiration date of the products was not investigated. All of them presented with dermatological reactions, and the main AR reported was redness in the skin (erythema). Most reactions were described as mild (56.6\%), and $9.2 \%$ were considered as severe by the interviewees. It is important to mention that the reactions considered as severe in this study were those that led the interviewees to search for medical care, to use some medicine and the ones in which symptom remission took longer. Only two people notified the reaction to the customer supportservice of themanufacturer, and 22 people saw a doctor because of the AR. Nobody used NOTIVISA.

\section{Conclusion}

The estimated prevalence of AR to cosmetics in this study found similar results to those of international studies ${ }^{4,5}$. The use of cosmetic products is universal, and the prevalence of AR requires a determinate focus on public health actions.

\section{References}

1. Brasil. Ministério da Saúde. Resolução no 79 de 28 de agosto de 2000. Estabelece a definição e Classificação de produtos de Higiene Pessoal, Cosméticos e Perfumes e outros com abrangência neste contexto. Diário Oficial da República Federativa do Brasil. Brasília (DF); 31 de agosto de 2000.

2. Sautebin L. A cosmetovigilance survey in Europe. Pharmacol Res 2007; 55(5): 455-60.

3. Anvisa. Relatório Anual de 2008: Ouvidoria. Brasília; 2009. Disponível em http://portal.anvisa.gov.br/wps/. (Acessado em: 04 de julho de 2012).
4. Di Giovanni AC, ArcoraciVD, Gambardella LBC, Sautebin L. Cosmetovigilance survey: Are cosmetics considered safe by consumers? Pharmacol Res 2006; 53(1): 16-21.

5. Willis CM, Shaw $\mathrm{S}$, De Lacharrière $\mathrm{O}$, Baverel M, Reiche L, Jourdain R, et al. Sensitive skin: an epidemiological study. Br J Dermatol 2001; 145(2): 258-63.

Received on: $12 / 10 / 12$

Final version presented on: 05/08/13

Accepted on: 07/19/13 